\title{
Impossibile
}

\section{Bernini in Piazza Navona}

\author{
FRANK FEHRENBACH
}

"Oh quanto mi vergogno di aver operato cosí male!" - "Shame on me for having done such a bad job," voiced the old Bernini under his breath, when, upon entering Piazza Navona, he saw his own Fountain of the Four Rivers, and with a sigh closed the curtain of his coach to remove the monument from his sight. ${ }^{1}$ This is hardly what one would expect from one of the most self-confident artists of all time, in view of what contemporary guidebooks enthusiastically described as one of the most beautiful fountains not only in Rome, but the entire world (fig. 1). ${ }^{2}$

Should one really take this account, reported in the biography of Bernini written by his son Domenico, at face value? Domenico's Vita of his father is far too meticulously crafted to permit the episode's Isolation. Seen in its context, Bernini's supposed selfrecrimination not only reflects one of the central motifs of this biography-extreme self-critique as a proof of both modesty and divine genius - but should also be considered along with other anecdotes surrounding the monument on Piazza Navona. First of all, it should be read as the aftermath and reversal of one particularly delightful anecdote, recounted by Domenico with great pleasure just a few pages before. The father again approaches his monument in a coach, this time at full speed, while thunder rumbles and a terrible storm damages the roofs of the palaces of Piazza Navona. The square is full of curious and frightened people anxious to see the recently erected obelisk tumble at any moment from its perforated base. Quite typically, some of the sensation-seekers even claim to witness the first movements of the giant block of pink granite. At this Point, Cavaliere Bernini arrives at full throttle, jumps out of his coach in a feigned panic, tearing his hair in

1. D. Bernini, Vita del Cavalier Gio. Lorenzo Bernino (Rome, 1713), P. 109. I would like to thank Caitlin Henningsen for her thorough

editing of my text, as well as Rudolf Preimesberger and Anthony Sigel

or their precious advice.

2. For an extensive discussion of the monument, see F. Fehrenbach,

(1640ndia Mundi. Gianlorenzo Berninis Fontana dei Quattro Fiumi

(1648-51) und Nicola Salvis Fontana di Trevi (1732-62) (Munich,

2008), pp. 15-201. mock despair, and asks the audience to step back in order to keep a safe distance. Then, walking nervously up and down, Bernini the comedian seems to have an inspiration. He stops, and with a bright smile asks a few men to "secure" the colossal needle with four thin laces, fixed with tiny nails to some adjacent buildings. At this point, Domenico reports, barely hiding his admiration, the first watchers begin to understand, and start roaring with laughter. The alarmists retreat meekly, and Bernini unhurriedly drives home through the storm. ${ }^{3}$

The artist's brazen bragging as a public actor in this story contrasts sharply with the later, aging Bernini's increasing devotion and seriousness, as underlined in his (cleric) son's biography; thus the juxtaposition of the two coach episodes. The thunderstorm anecdote, however, has its fundamentum in re. Indeed, with the spectacular construction on Piazza Navona, Bernini put his much-disputed reputation as an architect at stake. Admired by virtually every contemporary report, the Egyptian obelisk, which previously lay broken in five pieces in the Circus of Maxentius, appears to rest above its doubly perforated base with its numerous veins of water in a delicate equilibrium. As one contemporary source remarks, at first glance spectators perceived it tumbling before they realized its miraculous stability. ${ }^{4}$ With the unprecedented design of an obelisk above a "ruined" base eroded by countless rivulets, Bernini surpassed his paradigm: the five antique obelisks raised by pope Sixtus V (1585-1590), the first obelisks erected since antiquity. ${ }^{5}$ Bernini's risk-taking as an architect is even more astounding when compared to his desperate personal situation during the first years of Innocent $X^{\prime}$ s pontificate. Under the Pamphili pope's much-hated predecessor, Urban VIII Barberini, Bernini became the almighty and ubiquitous ruler of the arts in Rome, but

3. Bernini (see note 1), pp. 91-93. On Bernini's biographies, in particular Domenico's, see F. Mormando, The Life of Gian Lorenzo Bernini by Domenico Bernini (University Park, PA, 2011).

4. P. Totti, Ritratto di Roma moderna (Rome, 1652), p. 556.

5. See M. W. Cole, "Perpetual Exorcism in Sistine Rome," in The Idol in the Age of Art: Objects, Devotions and the Early Modern World, ed. M. W. Cole and R. Zorach (Farnham, 2009), pp. 57-76. 


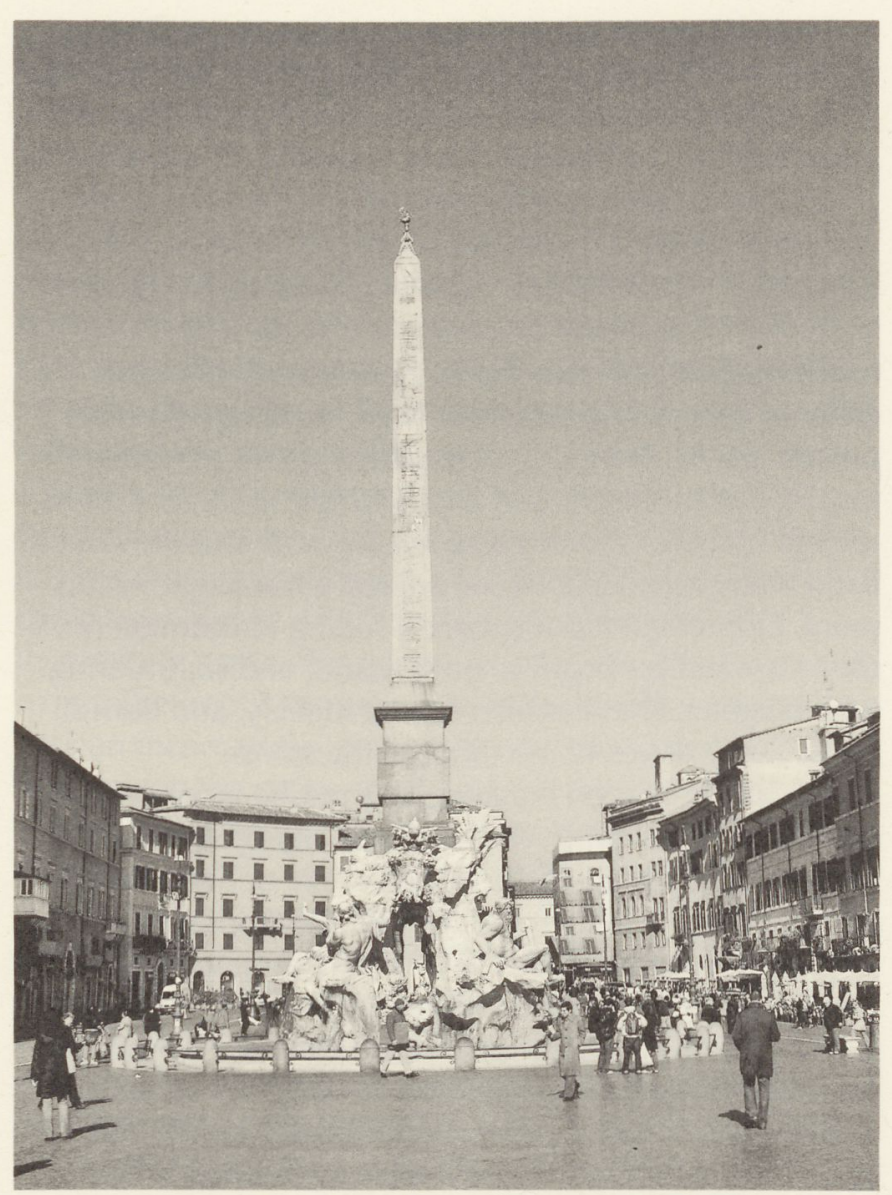

Figure 1. Gian Lorenzo Bernini and workshop, Fountain of the Four Rivers, 1648-1651. Travertine, marble, granite, and bronze. Piazza Navona, Rome. Photo: author.

things changed rapidly after the pope's death in 1644 . As Tod Marder and Sarah McPhee have shown in great detail, Bernini's plans for the bell towers of Saint Peter's turned into disaster and threatened to ruin the artist. ${ }^{6}$ As cracks caused by subterranean water currents appeared in the façade of the southern campanile, Innocent X had the upper stories and the enormous spire dismantled, and confiscated Bernini's assets. Cut off from all the major commissions of Innocent's early pontificate-left high and dry, as it were-Bernini's fate as an architect seemed doomed.

At this moment, Bernini decided to project the fact that his career was running dry into a giant monument

6. T. A. Marder, Bernini and the Art of Architecture (New York, 1998); S. McPhee, Bernini and the Bell Towers: Architecture and Politics at the Vatican (New Haven, 2002). of the perpetual antagonism of wetness and dryness that dominates one of the most important Roman piazze. His Fountain of the Four Rivers in Piazza Navona undermines the very foundation of architecture and sculpture-stability-and turns his work into a monument of challenge, and one of crisis.

In 1648, after an intrigue in which Prince Ludovisi had a helping hand, Bernini snatched the extremely prestigious commission for the central fountain of Piazza Navona from his archrival, Francesco Borromini. The pope's plans for a monumental fountain were part of the planned transformation of the entire square into a Forum Pamphilium, with the pope's palace, built by Girolamo Rainaldi and Borromini, extending from the southwestern end of the piazza toward its northern half. ${ }^{7}$ In this context, Bernini "went big" and tried to demonstrate publicly, on the magnificent stage of Piazza Navona, that all doubts concerning his architectural skills were unfounded. Not only did he unify a fragmented obelisk, hiding the joints of the single pieces perfectly, he also made it stand firm on "nothing," a void. ${ }^{8}$ At the same time, Bernini referred to his bell tower designs almost ostentatiously, with the fountain's four river gods at the corners of the structure replacing the fathers of the church, and an obelisk instead of a spire (both called guglia) hovering above the "void" of the belfry. Moreover, the wet soil underneath Saint Peter's metamorphosed into the artificial rock of the fountain with its many irregular water sources. The adventurous character of the project soon became evident when, in 1648, the scaffolding of the trench collapsed. At this point, as Theodor Ameyden reports, the pope was close to stopping an enterprise that stood to damage his own image considerably. ${ }^{9}$ It would have been more than a bad omen if this third erection of the Obeliscus Pamphilius had failed. After the ruin of the pagan empires of Egypt and Rome, the Christian re-erection of obelisks was expected to endure until the end of the world. ${ }^{10}$

7. See S. C. Leone, The Palazzo Pamphilj in Piazza Navona: Constructing Identity in Early Modern Rome (London, 2008).

8. See M. Lualdi, L'origine della christiana religione nell'Occidente, vol. 2 (Rome, 1651), p. 431; cf. G. Gualdi (Fabbriche di Roma, 1651) cit. in I. Herklotz, "Eine zeitgenössische Beschreibung von Berninis Vierströmebrunnen nebst einem Plädover für eine publikumsorientierte Kunstwissenschaft," in Opus Tessellatum: Modi und Grenzgänge der Kunstwissenschaft; Festschrift für Peter Cornelius Claussen, ed. K. Corsepius et al. (Hildesheim, 2004), p. 428.

9. Cited in S. Fraschetti, I/ Bernini: la sua vita, la sua opera, il suo tempo (Milan, 1900), p. 184, n. 3.

10. See, for instance, Fulvio Carduli on the obelisk of St. Peter's (1586); cited in G. Cipriani, Gli obelischi egizi. Politica e cultura nella Roma barocca (Florence, 1993), p. 36. 
Eventually, Bernini convinced the pope to trust in him, but nothing reveals the adventurous nature of the project more clearly than the clandestine circumstances of the obelisk's actual erection. Shortly before the fountain was completed, Virgilio Spada reported on his success in a surprisingly rapid execution, due to novel lifting devices. Bernini had let everyone know well in advance about the date of the erection in August 1649, but when the day arrived, he had his men begin their work secretly before sunrise. When the Roman population gathered in the morning, the "finger of the sun," as obelisks were called, already pointed heavenward - "to the general astonishment and disappointment of those who predicted a failure" (con maraviglia di tutti, e confusione di chi pronosticava disordini), as Spada quite tellingly concluded. ${ }^{11}$ Occurring at the crack of dawn, the decisive moment effected Bernini's triumphant rehabilitation without excess publicity. His aggrieved honor as an architect and the desire to make una bellissima figura were quite obviously countered by the fear of a complete disaster. In the process, Bernini synchronized the rise of the real sun with the erection of its symbol, the obelisk.

However, as a monumental fountain adorned by an obelisk, Bernini's architecture perpetuated the crisis of its maker and the crisis of its erection. As Rudolf Preimesberger showed in his magisterial, book-length article on the fontana, it was its urban location that prompted the combination of fountain and obelisk. ${ }^{12}$ Before Innocent decided to embellish the center of the piazza, a modest trough served as one of the three providers of fresh water at this most important Roman marketplace. The decision to adorn this particular fountain with an obelisk referred to the popular Conviction that Piazza Navona was, in Roman antiquity, a circus - a site of horse races, bloody gladiatorial bouts, and early Christian martyrdom. A most prominent victim, Saint Agnes, was venerated at an adjacent church before Borromini received the commission of the new building next to Bernini's fountain. The legendary name of the Circus Agonalis was transformed into "Navona" over the

11. See K. Güthlein, "Quellen aus dem Familienarchiv Spada Zum römischen Barock, 1. Folge," in Römisches Jahrbuch für Kunstgeschichte 18 (1979), p. 220, doc. 34.

12. R. Preimesberger, “Obeliscus Pamphilius. Beiträge zu Orgeschichte und Ikonographie des Vierströmebrunnens auf Piazza

avona," in Münchner Jahrbuch der Bildenden Kunst 25 (1974):

77-162. On the "Egyptian Renaissance," see B. A. Curran, The Egyptian

Renaissance: The Afterlife of Ancient Egypt in Early Modern Italy

(Chicago, 2007). course of the centuries (simultaneously alluding to its oblong, ship-like form and to the supposed performance of naval battles within the circus in antiquity). As contemporary reconstructions amply demonstrate, every circus was adorned by obelisks that towered along their spines (see fig. 2).

The erection of obelisks on sites that were primarily believed to host horse races was no coincidence. From Pliny, Isidore of Seville, and countless other authors, the educated knew that in ancient Egypt, obelisks were believed to represent a ray of the sun (digitus solis). ${ }^{13}$ But the horse races - or, more precisely, the races with quadrigas - also symbolized the sun, namely its course across the sky. The four horses of every coach and the four different colors of the competing teams represented the times of the day and of the year. Following Pirro Ligorio, the twelve gates from which the coaches started symbolized the months and the zodiac; the seven rounds the seven days of the week; and the twenty-four races the number of hours in a day. Even the three eggtopped metae at the turning points had cosmological significance: They alluded to the three astrological decans of every month. ${ }^{14}$ The circus was, therefore, perceived as a microcosm, with the central obelisk "above all dedicated to the sun, as Tertullian says; and according to Cassiodorus the circus represents the world around which the sun circles on its course," as Michele Mercati wrote in his widely diffused standard text on the obelisks of Sixtus V. ${ }^{15}$

It is precisely this antiquarian background of the most beautiful square in Rome, as contemporary sources defined it even before Innocent's interventions, which is reflected and amplified in Bernini's central fountain. Most importantly, neither the circus races nor the course of the sun across the firmament was free of risk; on the contrary, they were perceived as the theatrical and natural performances of crisis. Roman natural philosophers like Seneca, Ovid, and Lucretius insisted on the extremely vulnerable equilibrium of nature's elements and forces. The classic narrative of this endangered balance in nature, or more precisely, in the daily course of the sun-mirrored in the unpredictable

13. On the history and semantics of the obelisks, see B. A. Curran, A. Grafton, P. O. Long, and B. Weiss, Obelisk: A History (Cambridge, MA, 2009).

14. P. Ligorio, Delle antichità di Roma: circi, theatri, amphitheatri con numerose tavole e la pianta cinquecentesca di Roma, ed. D. Negri (Rome, 1989), pp. 55-56.

15. M. Mercati, De gli obelischi di Roma (Rome, 1589), pp. 236-237. 


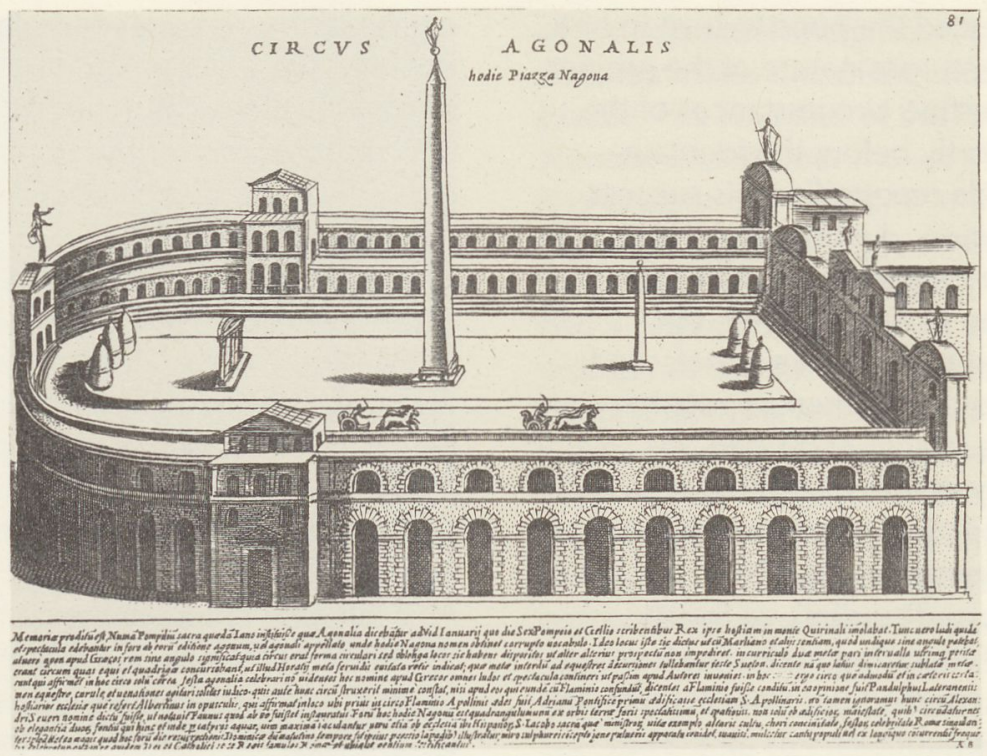

Figure 2. Circus Agonalis. Woodcut from Giacomo Lauro, Antiquae Urbis Splendor (Rome, 1625). Photo: Courtesy of Kunsthistorisches Institut in Florenz.

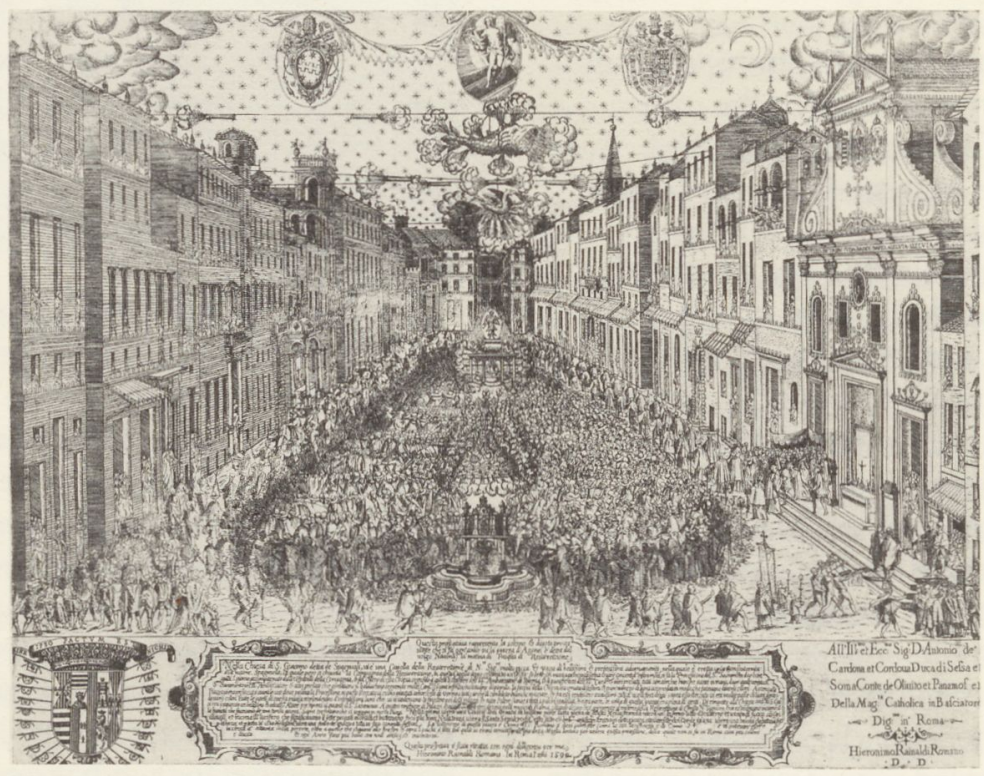

Figure 3. Girolamo Rainaldi, Procession on Piazza Navona, Rome, 1592. Etching. Photo: Courtesy of Albertina, Vienna.

course of the circus races, which were always threatened by disaster and failure-is provided by the story of Phaeton in Ovid's Metamorphoses. ${ }^{16}$ Indeed, Bernini incorporated elements of this myth in his Fountain of the Four Rivers, albeit without following Ovid to the catastrophic end of this cosmological drama. Accepting the basic assumption of all reconstructions of horse races in antique circuses including Piazza Navona-namely that the race begins at the straight end of the structure (on the southern edge of Piazza Navona) and runs 


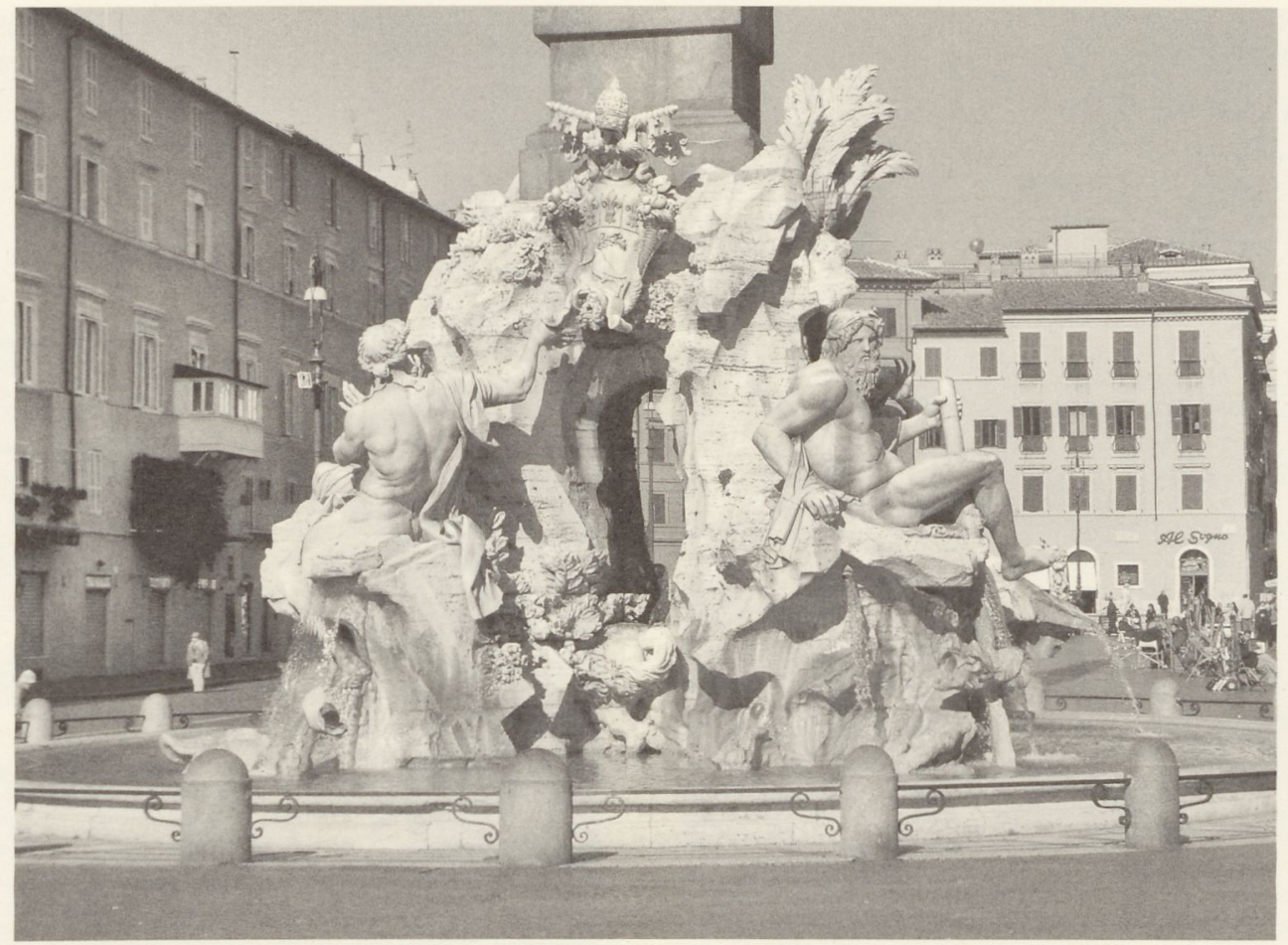

Figure 4. Gian Lorenzo Bernini and Claudio Poussin, Ganges, 1650-1651. Marble. Fountain of the Four Rivers, Piazza Navona, Rome. Photo: author.

around the obelisk in a counterclockwise movementBernini transposed the increasing danger of the sun's course as narrated in Ovid. Besides establishing the "dry" obelisk's spectacularly labile equilibrium on a perforated, "wet" base of rock, Bernini also took into account the progressive views of a mobile spectator in order to emphasize the miraculous overcoming of crisis as the central feature of his monument. Circus races Were supposed to have started in the area where, in Bernini's time, the two most important buildings of the square were located: the pope's palace and the Spanish church of San Giacomo. In an impressive case of the Nach/eben of antiquity, the spectacular processions of the Confraternity of the Resurrection continued in Bernini's time to circle the square in a counterclockwise direction, starting and ending at San Giacomo (see fig. 3). ${ }^{17}$ Bernini actually planned to synchronize the unveiling of the fountain with the procession on Corpus Christi in 1651, but had to postpone it by two days. Every spectator who approaches the fountain from the south is welcomed by the obelisk's southern inscription, inviting him or her to look carefully at the marvels of the monument; ${ }^{18}$ beholders are also received by the one river god who takes notice of them: Ganges (fig. 4). Attracted by spectacular details-a hissing dragon, a lion, the outstretched hand of an instable river god who seems to slip off his rocky seat-the spectator, moving around the monument counterclockwise, recognizes increasing degrees of agitation and concern in the river gods, but also more and more cracks and fissures in the obelisk's rising base. This dramatic structure, from relative calm to agitation, culminates in the panic of Rio della Plata who seems to doubt the obelisk's stability (fig. 5). It is at the west side of the fountain-the side where the sun comes closer to the earth each evening - where the signs of danger are amassed: a giant, hissing snake, a large stratum that apparently slipped diagonally downward, a horse in a state of horror that seems to dash away from its collapsing cavern. At this point the peripateia is reached, and the drama calms down. Danubius, the river of Europe, sits next to the pope's palace, remaining firm, upright, and extremely attentive (fig. 6). With his 


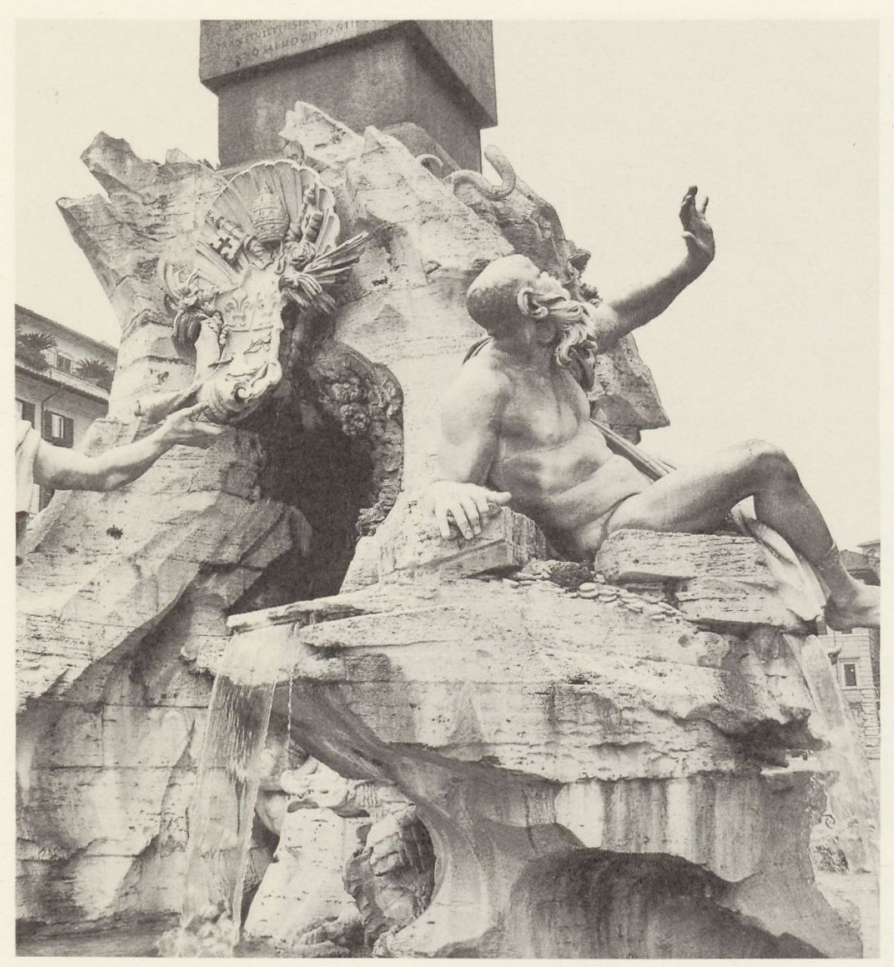

Figure 5. Gian Lorenzo Bernini and Francesco Baratta, Rio della Plata, 1650-1651. Marble. Fountain of the Four Rivers, Piazza Navona, Rome. Photo: author.

right hand he readjusts the slightly but spectacularly displaced papal coat of arms, ${ }^{19}$ while a large fish under his feet serves as the fountain's main runoff. Once again, everything is held together, and the heavy, dry "finger of the sun" remains in equilibrium on its wet support.

It comes as little surprise that most of the contemporary descriptions of the monument not only emphasize the spectacular statics of the obelisk above its perforated base, they also describe the individual features of the monument-though sometimes misidentifying the river gods - in a counterclockwise direction. ${ }^{20}$ Dramatic antagonisms and their necessarily labile equilibrium also mark the thematic core of Athanasius Kircher's monumental treatise on the obelisk of Piazza Navona, Obeliscus Pamphilius, published in 1650. ${ }^{21}$

Bernini received the commission for the Fountain of the Four Rivers in spring 1648, the year of the Peace

19. See F. Ackermann, "Berninis Umgestaltung des Innenraums von S. Maria del Popolo unter Alexander VII. (1655-1659)," in Römisches Jahrbuch der Bibliotheca Hertziana 31 (1996): 421-425.

20. For references, see Fehrenbach (see note 2), pp. 39-44.

21. See ibid., pp. 113-122; Curran et al. 2009 (see note 13), pp. $161-177$.

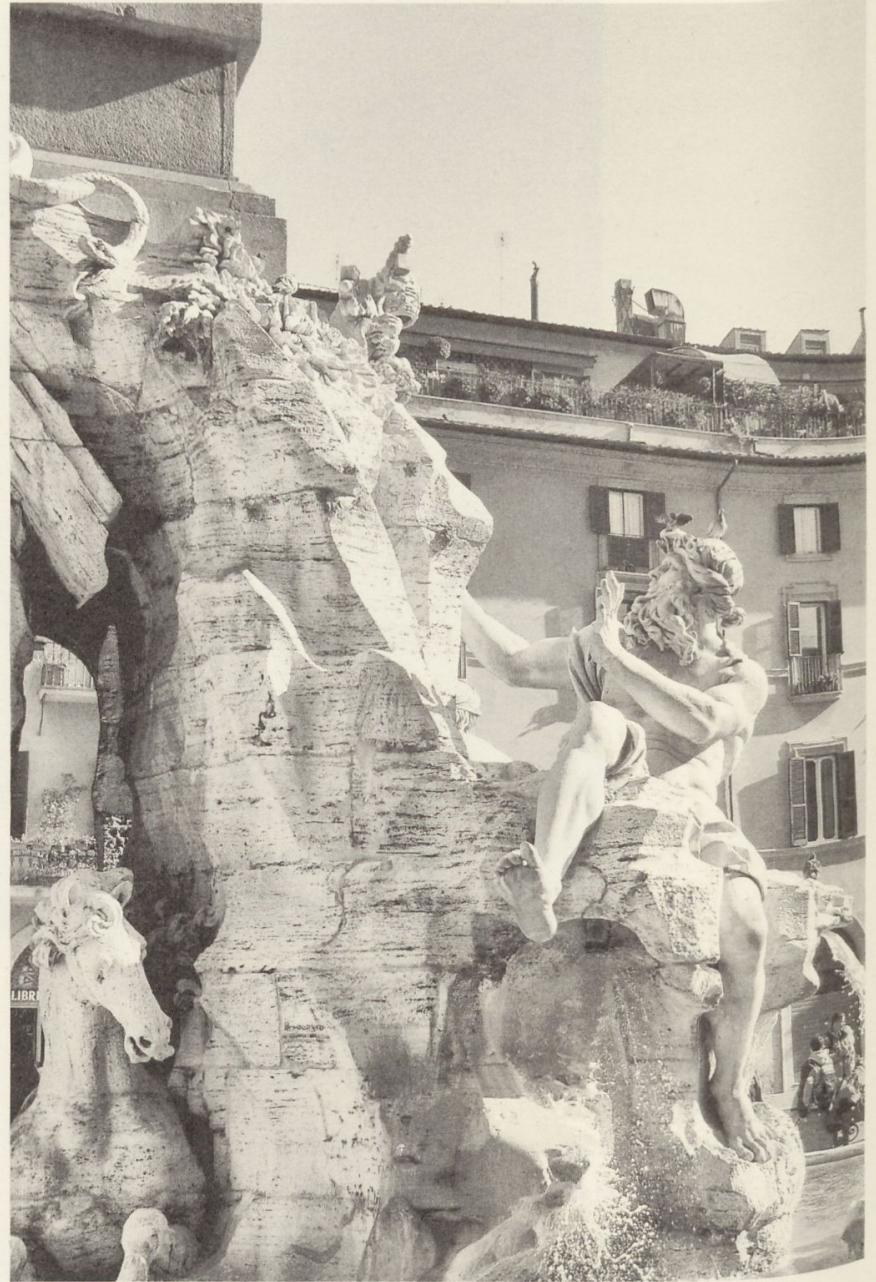

Figure 6. Gian Lorenzo Bernini and Antonio Raggi, Danube, 1650-1651. Marble. Fountain of the Four Rivers, Piazza Navona, Rome. Photo: author.

of Westphalia, the treaties signed in Münster and Osnabrück, and within sight of the Holy Year 1650, with its countless pilgrims entering the Urbs. In 1648, a disastrous and long war ended in which the Catholic Church and the Catholic emperor got off lightly, though filled with bitterness. It makes sense to relate the prominence of Danubius-iconographically a rather unusual representative of Europe- to the final success of Ferdinand III in his Austrian Erblande, followed by a thorough Catholic restoration in this area..$^{22}$ As a monumental realization of Alciati's emblem of peace, Ex pace ubertas (fig. 7), Bernini's fertile rocky island

22. See M. Christian, "Bernini's 'Danube' and Pamphili Politics," in The Burlington Magazine 128 (1986): 354-355. 
became the perfect monument for the end of war. In its emphasis on the endangered equilibrium, the fountain mirrors a formula that, during the peace negotiations, became for the first time a guiding principle in European politics: Aequilibrium, quite significantly a motto first put forth by the weakest party, the church itself. ${ }^{23}$ However, the implications of the monument's permanent spectacle of endangered balance went further, and they aimed at none other than the ruling pope. It is Innocent himself, represented in his heraldic animal, the dove, which rules with a light foot over the entire structure, as a contemporary panegyric put it. ${ }^{24}$ In its calm repose atop a virtually instable obelisk, oriented toward the rising summer sun in the northeast and carrying the olive branch of peace in its beak, the dove alludes to one of the most frequently applied topoi of praise at the beginning of Innocent's reign: the desire for peace, realized by the new Noah, after the excess of wetness, the "deluge" of the previous wars.

These expectations, however, turned out to be mere wishful thinking. Oscillating between lethargy and irascibility, Innocent surprised everyone who remembered him as a peace-loving opponent of Urban VIII's war against the Farnese over the Duchy of Castro, some fifty miles north of Rome. The spectacular flight of the Barberini cardinals to France after Pamphili's election had already set the tone of his pontificate. Two years after Innocent's reconciliation with the nipoti of his predecessor in 1647, Innocent received news of the murder of Castro's bishop. Beside himself with rage, the pope ordered the total destruction of the town, an act of brutality unprecedented in early modern Italian warfare. ${ }^{25}$ After the discovery of spurious bulls in 1652 an event that supposedly caused a permanent tremor in the pope's right hand-he had Mascambruno, the mastermind of the forgeries, tortured and killed in cold blood along with over a hundred members of his circle. ${ }^{26}$ The unpredictability of the leery jurist was notorious. Ludwig von Pastor summarized laconically: "His

\footnotetext{
23. See J. Burkhardt, "The Summitless Pyramid: War Aims and Peace Compromises among Europe's Universalist Powers," in 1648: War and Peace in Europe, ed. K. Bussmann and H. Schilling (Münster, 1998), vol. 1, pp. 51-60.

24. A. Bernal di Gioya, Copiosissimo discorso della Fontana, e

Grglia Eretta in Piazza Nauona, per ordine della Santità di Nostro

Signore Innocentio X. Dal Signor Caualier Bernini (Rome, 1651), p. 2.

25. See H. Giess, "Die Stadt Castro und die Pläne von Antonio da

angallo dem Jüngeren," in Römisches Jahrbuch für Kunstgeschichte 17

(1978), 47-88, and 19 (1981), 85-140.

26. G. Eimer, La Fabbrica di S. Agnese in Navona. Römische

Architekten, Bauherren und Handwerker im Zeitalter des Nepotismus,

vol. 1 (Stockholm, 1970), pp. 70-73.
}

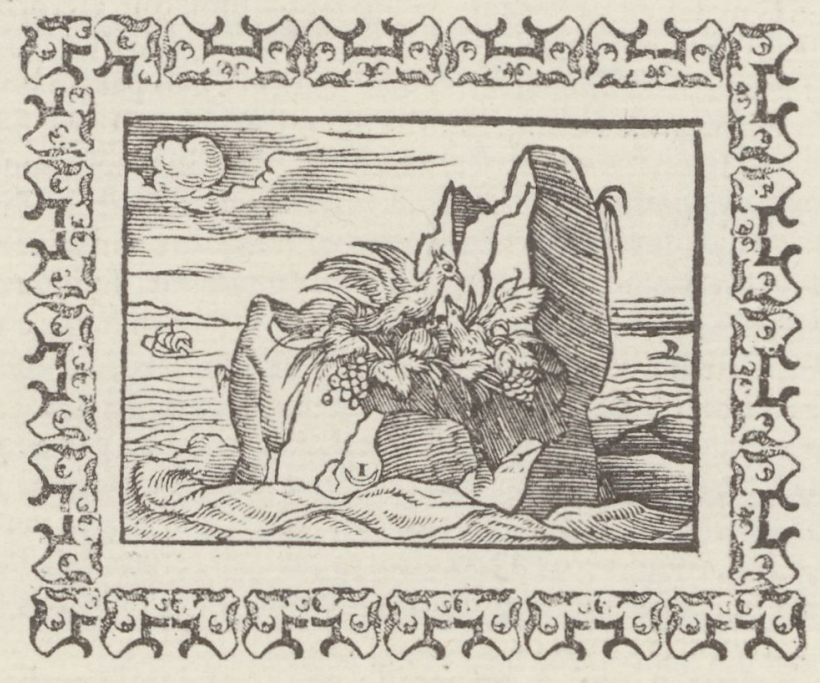

Figure 7. Ex pace ubertas. Emblem CLXXVIII from Andrea Alciati, Emblematum liber (Paris, 1583). Photo: Typ 625.21.132, Houghton Library, Harvard University.

irascibility made it difficult to get along with the sullen man, who changed grace into disgrace according to his instable moods." ${ }^{27}$ However, the pope himself apparently suffered under his weakness and the obligations of his office: "One day, in view of the ferocious struggle between France and Spain on every field, the pope complained that it was very hard for him to keep an equilibrium; and that he felt as if he had to walk continuously on a tightrope of silk" - an almost perfect reference to Bernini's monument. ${ }^{28}$

Bernini himself was a victim of the pope's mood swings. However, he did not refrain from challenging his fate. The revengeful decision of the committee (with the pope's approval) to demolish Bernini's bell tower followed directly from a satire on stage, during carnival 1646 , in which Bernini the actor mocked the pope as an indecisive doter, and his nephew, Cardinal Camillo Pamphili, as a greedy bootlicker. ${ }^{29}$ Bernini must have felt continuously provoked to push the envelope. Long after his reconciliation with the pope, he made the old man himself an actor under his direction. When Innocent visited the site of the Fountain of the Four Rivers in summer 1651, everything appeared to be complete,

27. L. von Pastor, Geschichte der Päpste seit dem Ausgang des Mittelalters, vol. 14, no. 1 (Freiburg im Breisgau, 1960), p. 28.

28. Ibid., p. 57.

29. See Fraschetti (see note 9), p. 270, n. 1. 
but the water was still lacking. At the end of his visit, Domenico Bernini reports, the disappointed pope left the scene reluctantly, blessing the artist before he left the fenced site. At the very moment when he turned his back to the fountain, Bernini ordered the pipes opened, creating a majestic spectacle and gathering the cheers of an enthusiastic pope. ${ }^{30}$ The message was clear: while his art depended on papal benevolence, it was he, Bernini, who ruled over wet and dry.

But Bernini had much more in mind. This was immediately clear in the summer of 1652 , when, according to the diarist Gigli, the runoffs of the fountain were sealed and the southern part of the piazza flooded for some weeks. ${ }^{31}$ The allagare, as it was called, became one of the major spectacles of Rome in the centuries to come, a major relief for both Romans and visitors suffering under the unbearable heat of the solleone. It comes as little surprise that the corso of the coaches driving slowly through the knee-deep water circled around the Fountain of the Four Rivers in a counterclockwise movement, as prints by Giuseppe Vasi and Francesco Corsi, among others, demonstrate. The artificial deluge on Piazza Navona visualized and expanded the precarious equilibrium of the Fountain of the Four Rivers. The heterogeneous elements of the obelisk and the perforated rock, with its many irregular outlets of water, demonstrated the basic antagonism of fire (obelisk) and water. The flooding of more than half of Piazza Navona transformed the fountain into an increasingly expansive, literally immersive monument. Accordingly, in May 1653, a papal chirograph ordered another figure for another fountain, in front of the church of San Giacomo. One month later, a papal act specified that it should be a full figure (statua in tutto), directly in front of the main entrance of the Palazzo Pamphili (fig. 8). ${ }^{32}$

Bernini's Fountain of the Four Rivers visualized a plea for equilibrium and stability against the threat of disaster. Innocent was an ideal -addressee for this plea, which was, according to the rules of panegyrics, disguised as a hyperbolic compliment for a marvelous achievement. With the central figure of the southern fountain Bernini amplified this message. Identified in the seventeenth century as Tritone, statua nuda, or more rarely, Nettuno, the figure shows obvious formal allusions to one of Bernini's favorite antique works, the fragmented, nearby statue of Pasquino. However, with his bulging lips and

30. Bernini (see note 1), p. 90.

31. See M. Fagiolo, "La scena delle acque," in Gian Lorenzo Bernini: Regista del Barocco, ed. M. G. Bernardini and M. Fagiolo dell'Arco (Milan, 1999), pp. 137-146.

32. See Fraschetti (see note 9), p. 202.

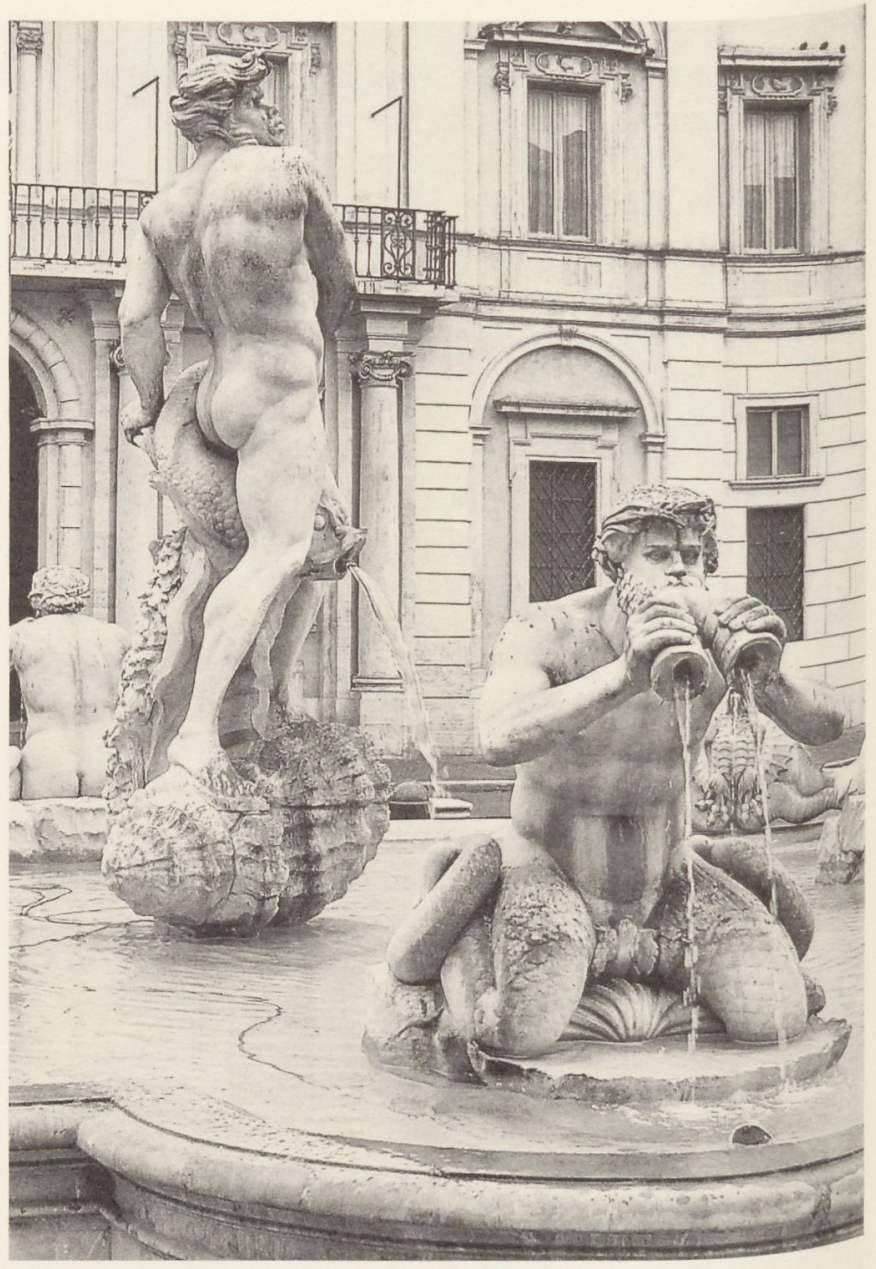

Figure 8. Gian Lorenzo Bernini and Giovanni Antonio Mari, statue of the "Moor," 1653-1655. Marble. Piazza Navona, Rome. Photo: author.

his broad nose, Bernini's figure is, in fact, a close relative of Rio della Plata, who was referred to as a "Moor" or "Ethiopian" in contemporary descriptions. The modello for the statue now in the Kimbell Art Museum and the small terracotta in the Palazzo Venezia emphasize these "Moorish" features even more than the executed statue.

33. One of the earliest sources identifying the figure as a Moor is an inventory from 1767 of the Palazzo Chigi on the Corso: "the other" [statue] in terra-cotta representing the model for the statue of the MoO in the fountain in Piazza Navona by Bernini"; cit. in F. Petrucci, "The Interiors as shown in some Archive Photographs before 1918," in Palazzo Chigi, ed. C. Strinati, R. Vodret Adamo, and M. G. Barberini (Milan, 2001), pp. 106-107; see also S. McPhee, Bernini's Beloved: A Portrait of Costanza Piccolomini (New Haven, 2012), p. 97. On the Kimbell modello and the fountain, see the essays in A. Butterfield, Bernini: The Modello for the Fountain of the Moor (New York, 2002). 
In Francesco Ascione's Canzonetta on the Fountain of the Four Rivers, written in 1651, the features of Rio della Plata are celebrated: "Mostra il viso esser di Moro, / Ma di bianco il marmo ha specchio (. . .). ." ${ }^{134}$ Ascione's brilliant juxtaposition of white marble and black skin echoes the woodcut illustrating Alciati's emblem LIX with the motto Impossibile: A moor is sitting on a block of stone, while two white men try to wash his color away with the waters of a fountain. The epigram (by Lucian) reads: "Why do you vainly set about washing off the Ethiopian? Ha, ha! Give it up: nobody can ever enlighten the shadows of blackest night." ${ }^{15}$ The blackness of the Ethiopian is a direct result of Phaeton's catastrophic journey close to earth, which "burned" the skins of Africans, as Alciati underlines, referring both to Pliny and Ovid. But it is Alciati's interpretation that relates the emblem to Bernini's fountain; he follows Jeremiah 13:23: "Can the Ethiopian change his skin, or the leopard his spots? Then may ye also do good, that are accustomed to do evil." As Alciati's motto indicates, the emblem illustrates the impossibility of changing "nature" - or more precisely, the bad habits of the human character. "Mores vel animum mutare difficile," reads the Conclusion at the margin. ${ }^{36}$ The whitewashing of the Moor is a perfect adynaton-the rhetorical figure of an impossibility. As the ass's stubbornness shows, unruly and obstinate minds cannot be changed by any force or art: "mores indociles, \& indomitam quamdam naturam, quae nulla vi aut arte mitescere potest." ${ }^{137} \mathrm{~A}$ later elaboration of Alciati's emblem by Aegidius Sadeler II Provides scattered elements of what appears to prefigure Bernini's coherent ensemble on Piazza Navona: a circus, a high-rising obelisk, a fountain with a large fish, and next to it the poor subject of a futile skin treatment (fig. 9). Nobody, not even Innocent himself, could, in the end, overcome the pope's mood swings and his lack of equilibrium. Anger turned him "black" repeatedly, poner negro, as the Spanish idiom says, which must have been quite familiar to Innocent, who had served as a nuncio in Madrid. Washing away the Moor's blackness

\footnotetext{
34. Cit. in Fraschetti (see note 9), p. 201.

35. "Abluis Aethiopem quid frustra? Ah desine: noctis / Illustrare nigrae nemo potest tenebras." A. Alciati, A Book of Emblems: The Emblematum Liber in Latin and English, ed. and trans. J. F. Moffitt Uefferson, NC, 2004), p. 78. On the history of the topos see J. M. Massing, "From Greek Proverb to Soap Advert: Washing the Ethiopian"

in idem, Studies in Imagery, vol. 2, The World Discovered (London, 2007), pp. 281-314.

36. A. Alciati, Emblemata cum commentariis amplissimis [. . .]

adua, 1621), p. 274

37. Ibid.
}

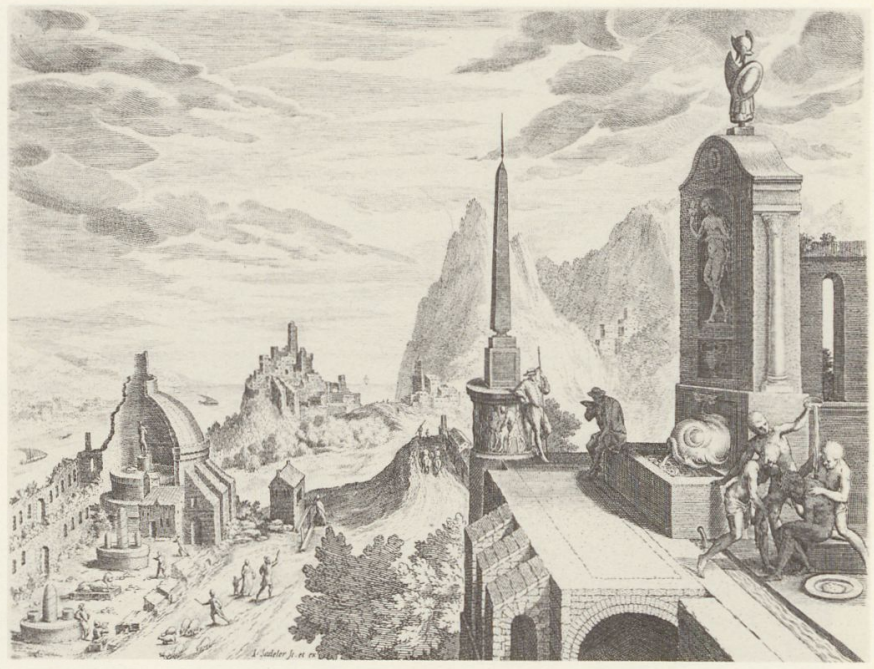

Figure 9. Johannes Sadeler I, Rocky Landscape with Antique Buildings. Engraving. Late sixteenth century. Photo: Courtesy of The Metropolitan Museum of Art New York, The Elisha Whittelsey Fund, 1951).

is impossible by any power or art-or is it? Bernini prudently avoided a provocative, blatant statement, but he presented his "Moorish" Triton in front of the Palazzo Pamphili's main entrance, in immaculate white Carrara marble. To this artist, nothing was impossibile, neither the whitening of the Ethiopian, nor the erection of a reassembled obelisk above "nothing" and water, nor the revivification of Pasquino, nor, as Bernini himself put it, the "bending" of marble like wax, or pasta. ${ }^{38}$ As an athlete of crises, he is able to perpetuate critical turning points in his works - the transformation of flesh, the reverberations of the embodied soul, the last breath of a dying body. Young Bernini carefully staged the crisis of physical pain by holding his arm to a flame, in order to study his expression in a mirror (while his skin first dried, then turned black, as it were) and imitate himself subsequently in the sculptural agony of his patron saint, Lawrence..$^{39}$ The mature master triumphed on the stage of the permanent crisis that distinguishes the true artist. Or, in Bernini's own words, as recalled by an admiring Paul Fréart de Chantelou: "Chi vuol veder quel che un uomo sa, bisogna metterlo in necessità" - "If you want to see what a man knows, put him in a difficult position." ${ }^{40}$

38. Bernini (see note 1), p. 149

39. Ibid., p. 15.

40. P. Fréart de Chantelou, Journal de voyage du Cavalier Bernin en France, ed. M. Stanić (Paris, 2001), p. 239. Translation in D. Bernini, The Life of Gian Lorenzo Bernini, trans. F. Mormando (University Park, PA, 2011), p. 303. 




Figure 3. Peter Paul Rubens, Adoration of the Magi (detail). Photo: Erich Lessing/Art Resource, New York 